\title{
Remote Religion / Remote Region: Practicing and Researching Remote Religion in the Andaman Islands
}

\author{
Raka Banerjee \\ Advanced Centre for Women's Studies, \\ Tata Institute of Social Sciences, Mumbai \\ banerj.r@gmail.com
}

Publication Information:

Received 7 November 2021, Accepted 8 December 2021, Available online 28 December 2021

DOI: $10.21463 /$ jmic. 2021.10.2.07

\begin{abstract}
Remoteness is an attribute that has often been negatively attached to island-spaces like the Andaman Islands, separated from the Indian mainland by the vast Bay of Bengal, located at the 'liquid borderlands' of South and Southeast Asia. The Covid-19 pandemic, on the other hand, has popularised the use of 'remote' methods of enabling religio-social interaction. The islanders of these geographically 'remote' locations use these 'remote' ways of connecting to perform their religious practices and maintain their faith networks, which is otherwise compromised due to the pandemic-induced restrictions on social gatherings. By exploring the 'online' global faith networks of the little-known Matua religion, as well as, the social, technical and logistical constraints in the devotees' access to 'remote' religion, the paper addresses two questions: first, how do individuals play out their identities, both as islander and as devotee, 'online'; second, what are the corresponding technological and logistical conditions that enable their 'presence' and who are the 'absent' actors. Drawing from remotely collected data, particularly online ethnography and telephonic interviews, the paper explores the mediating role of technology in destabilizing, as well as, solidifying concepts of remoteness and isolation, particularly in the peripheries of nation, during times of restricted mobility.
\end{abstract}

\section{Keywords}

Remoteness, Gender, Religion, Andaman Islands, Bay of Bengal, Matua 


\section{Introduction}

Andaman Islands, located in the Bay of Bengal and the Andaman Sea, is separated from the Indian mainland by almost one thousand kms from the mouth of River Hooghly. In late-March 2020, the first reported case of Covid-19 infection was traced to an island-bound group of residents returning from a religious congregation in mainland India. On the one hand, the Island's distance from the mainland offers insularity against the spread of infectious diseases, like Covid-19. But on the other hand, the 'remoteness' and 'insularity' of the islands, coupled with imposition of pandemic-norms of social distancing and 'isolating', compound the islanders' sense of disconnect. In order to historically contextualize this sense of disconnect and the islanders' ways of connecting, one needs to reflect on the circumstances which led to their emplacement in the Islands and the crucial role of Matua religion in providing an antidote to 'remoteness'.

Andaman Islands have historically experienced a high influx of migrants and its social composition can be seen as prototypical of migration societies with multicultural island communities as a result of these voluntary and involuntary migration flows (Baldacchino and Veenendaal, 2018: 347). The principle of 'terra nullius' (Abraham, 2018; Sen, 2017a; Zehmisch, 2018) informed the policies of settlement in the Islands and the notion of 'disposability' of population, both in circumscribing the space of indigenous populations and in the transportation of populations from the mainland, was employed to populate its settlements. The multicultural, multi-ethnic population of the Andaman Islands has come into being as a result of migration - directed and planned by the state, as well as, independent movement of populations and social engineering policies of the colonial and the post-colonial times (Zehmisch, 2012). These social-engineering policies resulted in the settlement of several mainland communities, including the Bengali 'Hindu' refugees and migrants of India's eastern partition (1947), into the Islands. Matua faith, which began as a "philo-Buddhist, Dalit, anti-Brahmanical movement" (Lorea, 2017: 4), arrived to the Andaman Islands on the back of the displaced Namasudra (lower-caste population in Bengal who were the worst affected of the Partition refugees and had little or no resources to start over in India) refugee population coming from East Pakistan (present-day Bangladesh) into India, whereafter they were dispersed across the country (Mallick, 1999; Chatterji, 2001; Jalais, 2005; Anderson et al., 2016; Sen, 2017, 2018; Lorea, $2017,2020)$. During the population enumeration of 1872, upper-caste officials registered the lower-caste Namasudra population as derogatory 'chandal' (a pejorative term referring to people of the lowest rung in the caste hierarchy, who were treated as untouchables by the upper-caste Hindus) resulting in massive protests under the patronage of Harichand Thakur and his son Guruchand Thakur (Byapari, 2013). These protests took place in four districts - Barishal, Khulna, Faridpur, Jessore - of undivided Bengal. Eventually, in 1911, the title was reversed to 'Namasudra'. It was Harichand and Guruchand Thakur who called for espousing Matua religion, rejecting the existing caste hierarchy and its oppression. Namasudras formed the largest caste group in undivided Bengal but their lower economic position and lower caste position rendered them the most vulnerable population subject to the many undulations of Partition and policies of rehabilitation (Bandyopadhyay, 2016). According to Mazumdar (2016: 198), the Matuas constitute over eighty per cent of the Bengali settler population in the islands. ${ }^{1}$ This dislocation meant the once united and politically significant population (Jalais, 2005; Sen, 2015) was now dispersed across the Indian territory in "areas culturally and physically removed from the refugee's known world" (Jalais, 2005: 1758), Andaman being the farthest of them all. Under these circumstances, faith was of utmost importance in creating a sense of 'home' and 'homeland' (Lorea, 2017). It is through cultural traditions, observance of religious festivals, and music performances that this population dealt with their physical and cultural isolation (Lorea, 2017: 4). The series of rapid changes and uncertainties as a result of the Covid-19 pandemic has yet again raised questions around social proximity, island-mainland relationship, and ways of practicing religion through creative means. 
The availability of virtual avenues has allowed Matua islanders to practice religion online, turning traditional in-person religious meetings (hari sabha) into Zoom e-hari sabhas (devotional gathering); transformation of the oral 'haribol' (uttering the Lord Hari's name) chant to the written word in Facebook comments; publication of a Matua phone directory create a database of devotees; livestreaming devotional music sessions; and finally, the use of platforms like YouTube to watch kirtan (singing in praise of the Lord) videos and listening to religious texts. Furthermore, the use of multiple languages (Bangla, Hindi and English) also helps accommodate the linguistic preferences of Matua devotees spread across the mainland (particularly in the north Indian states of Uttarakhand, Uttar Pradesh and Haryana, as well as, in Madhya Pradesh and Chhattisgarh in central India). In this context, connectedness acquires multiple layers of meaning as the geographical island-space is separated from the mainland by the Bay of Bengal; the Matuas are separated from their religious homeland, Orakandi in present-day Bangladesh, by international borders; and finally, the tangible infrastructures that allow for connectedness (like internet connectivity) are not regularly available at the inter-island scale. The presupposition of virtual avenues often obscures the precondition of requisite tangible infrastructures that allow for manifestation of islanders' 'connectedness' through faith practices. While taking their socio-cultural and religiopolitical expressions, communications and debates to the virtual media, creates new ways of forging connections for the Matuas, which is especially significant in the contemporary times, it also leaves out certain actors from the process. The unequal access to technology - by virtue of living in 'peripheral' physical locations, as well as, marginalised social location on the basis of caste-class-gender - has varied manifestations in the physically-distanced times of the pandemic. Based on this premise, the paper explores two questions: first, how do Matua islanders play out their identities, both as islander and as devotee, 'online'; second, what are the corresponding technological and logistical conditions that enable their 'presence' and who are the 'absent' actors. The following section introduces the methodological framework of the research. It is followed by two broad sections in response to the questions set forth by the paper: first, a demonstration of and deliberation on the performance of 'islander' and Matua identities in the islanders' online interactions; and second, a case for putting into record the accounts of actors that are absent from such 'virtual' spaces. In doing so, the paper teases out the themes of islanders' online interactions while highlighting the silences in these interactions and the ways in which these silences are produced.

\section{Methodology}

The paper primarily draws from experience of conducting remote data collection, particularly online ethnography and telephonic interviews, for the research project 'Religion Going Viral: Pandemic Transformations of Religious Lives and Ritual Performances in Asia', at Asia Research Institute, National University of Singapore. It also uses Island Studies literature and literature on India's (eastern) Partition, and insights from my doctoral research with the Bengali settler women in Andaman Islands, to contextualize the social location of the interlocutors, as well as, the significance of their geographic location, vis-à-vis, Matua religion. The paper uses data gathered by two methods of remote data collection: first, conducting a 'digital ethnography' (Hine, 2000, 2017) or 'netnography' (Kozinets, 2010) of Port Blair-based 'Matua preacher and social worker' Animesh Mandal's (name changed) Facebook interactions and online activities between mid-March 2020 to February 2021; and second, conducting multiple rounds of telephonic interviews with five interlocutors (one woman and four men) based in different parts of the Islands (namely, Port Blair, Junglighat, Wandoor, Diglipur and Swaraj Dweep or Havelock Island) between late-October 2020 to early-February 2021. This approach allowed me to observe the 'field' as it unfolded 'online', as well as, gather in-depth data from participants over a prolonged period. Further, the netnographic observations equipped me with updated information on the Islands, which I then used to guide my interactions in conducting telephonic interviews. 
I have employed data from the online ethnography and the telephonic interviews with participants to understand the mediating role of technology in destabilizing, as well as, solidifying concepts of remoteness and isolation, particularly in a region like the Andaman Islands, at the peripheries of nation, during times of restricted mobility. However, these online exchanges alone do not amply illuminate their 'practices of meaning-making' (Hine, 2017: 22). The online interactions, via publishing posts, 'comment'-ing, 'like'-ing, or debating, create this social network, hence the agency of users makes the technology what it is in the specific context (Hine, 2017: 23). Moreover, in selecting what is studied the researcher creates the 'field' (Hine, 2000, 2017). As a non-participant observer conducting this netnography, these online exchanges are my 'text' that become meaningful in the cultural context in which it is situated (Hine, 2000: 52). Telephonic interviews as a method of qualitative data collection, on the other hand, enables the possibility of capturing and ethically representing the participants' responses, but it relies on the participants' access to technology. In case of developing countries, as Mani and Barooah (2020) point out, members of a household often share mobile phones, as a result, not all members have equal access to the phone, which is especially disadvantageous for women and older members of the family. In this context, it is interesting to note that my sole female participant was the only one to prefer that I refrain from recording our interaction, as she was 'not sure if her responses would be of much importance and would probably not require recording'. Further, individuals without access to phones, or with unstable phone networks, got automatically excluded from the process of data collection, rendering them 'absent' from the narrative around religion-region in the time of the pandemic. In most cases my interlocutors would suggest that I come to the Islands after the restrictions are lifted, and then we could speak at length without the complications associated with the Island's phone network connectivity, suggesting a preference for on-site embodied multisensory exchange over virtual means.

\section{Performing 'islander' and Matua identity online}

Facebook friend: "Amar koti proshno ache: 1. Chhinnomulder she shomoye bari korar tin diyechilo? Shonge arthik shahajya o bari korar annanyo shamogri diyechilo? 2. Ration diyechilo? Kotodin diyechilo? 3. Ration'er shonge arthik shahajya diyechilo? Kotodin diyechilo?"

Animesh Mandal: "Haan kaku, amader shurute tin, goru, langol, artho, rannar hari-kuri, thala, bashon, proti poribare ekta kore doodher gai, duti ere goru, shurute ration free chhilo. 15 bigha jomi, ekti house site, $15 \mathrm{cu} / \mathrm{mtr}$ free 'rayalty' timber with one cubic for 'dungi' construction, in anather (sic) scheme 10 hectares land including hilly land, etc."

(Facebook friend: I have a few questions: 1. Were the uprooted people given tin sheets for constructing houses? Were they also given financial support and other provisions necessary for such construction? 2. Were they given any rations? How much? 3. Were they given any doles in addition to these rations? How much?

Animesh Mandal: Yes uncle, in the beginning we were given tin, farm equipment, kitchen utensils, one milch cow and two bullocks per family, and free ration, initially. 4.9-acre land, one house site, $15 \mathrm{cu} / \mathrm{mtr}$ free timber with one cubic metre for constructing a dinghy; yet another scheme had provision for offering 10 hectares of land including hilly land, etc.)

The above exchange of $28^{\text {th }}$ July 2020 on Animesh Mandal's, a Port Blair-based Matua preacher, Facebook timeline stood out to me both because of its content, as well as, the participants involved. While Matua devotees' Facebook groups and profiles are aplenty, only few profiles belong to residents of Andaman Islands even though the islands have a sizable Matua population. One of the most active of these profiles belong to Animesh Mandal who hails from Little Andaman, while his Facebook friend's profile states that he studied in Jessore and Dhaka, and retired from service with 
the Government of India. Now based in Kolkata, his journey to India must have had a certain degree of similarity with that of Animesh Mandal's (or his parents' and grandparents') journey to mainland India and later, to Andaman. Interactions between them, starting from the early days of lockdown (March 25) is different from Animesh Mandal's other Facebook friends. In his post regarding the pandemic, the Facebook friend writes, "Andaman'e apni corona'r shob pouchhe din amader shokol Matua poribar k. Shokole shushtho thakun. Ektu gramanchole prokop kom kintu shabdhan thakte hobe. Mainland bipod beshi" (Please spread the awareness regarding corona to all our Matua families in Andaman. Stay well, everyone. The impact is a bit less in the rural regions, but one has to stay on guard. It is more dangerous in the mainland.). This sentiment, reiterated by islanders in telephonic interviews, upholds the island-space as 'sanitized' and 'safe', as well as, rural and therefore, 'backward' at the same time (Burholt et al., 2013; Baldacchino, 2018; Royle and Brinklow, 2018). In the context of the pandemic, however, rurality has also been projected as a positive attribute in evading the virus, as Covid-19 has often been understood as an urban disease. I explore the 'online' social interactions on a prominent Matua religious preacher's Facebook profile, to highlight the interrelated nature of 'islander' and 'Matua' identities informing virtual interaction. The aim is to take a critical look at these online religious deliberations not only tool for promoting a sense of community during a long period of lockdown and ongoing social distancing, but more significantly the permeation of 'islandness'2 (Baldacchino, 2018) and the displaced community's history of 'islanding' (Larjosto, 2020) in interactions around Matua religious identity and belonging.

The demise of Gopal Maharaj, one of the prominent Matua preachers to visit the Andaman Islands and facilitate the spread of Matua religion among the island's Namasudra settler population, provides an epistemic window to reflect on this religion-region interface. Shortly after his demise on 19th October 2020, Animesh Mandal shared his immense contribution to the Matua cause, when a young Gopal gosain (spiritual healer) travelled through water for five days and five nights to reach the Andaman Islands in mid-1970s to early 1980s. He toured across the islands, spreading the word of Hari and established ten temples in various locations for the spread of Matua faith. His passing deeply affected the island's Matua community and they collectively decided to be in mourning for eleven days, consuming only vegetarian food, and ending the period of mourning by organizing a communal feast. Due to unavailability of flight facilities, Animesh Mandal was unable to travel to Uttarakhand where the Maharaj's funerary rites were performed. His ashes, the post read, were to be sent across to all sixty-five temples established by the late Maharaj. Curiously, Animesh Mandal chooses to refer to his location as "shudur Andaman dwip" (distant Andaman Island) in his posts. In the following weeks, memorial meets were organised in Hari mandirs across the island, particularly in Sippighat hari mandir near Port Blair, and in other locations like Ramnagar, Diglipur, Rangat, Billyground, Shaheed Dweep, Swaraj Dweep and Little Andaman. On $1^{\text {st }}$ November 2020, "sarkari protocol mene" (in adherence of all government protocol) the island's devotees paid their respects to the late Maharaj by reciting the sacred text Sri Leelamrita, narrating the Maharaj's life philosophy, performing devotional music sessions, and finally, offering flowers and fruits to the "gangarupi" (akin to the Ganges) ocean. The event was attended by over hundred devotees. Further, the homeopathy medicine 'Arsenic Album-30', which was marketed as a Covid-19 preventative but later debunked (Mehra et al., 2020), was distributed free of cost to all attendees. In sharing images of these events along with images of events taking place in his ashram in Dineshpur, Uttarakhand, Animesh Mandal creates a sense of shared geography of faith network tying the island closer to the mainland while also invoking its 'distant' aspect by using descriptors like "shudur Andaman dwip". In a similar vein, telephonic interview participant Ashok Pal ${ }^{3}$ (name changed) - who also features in some of Animesh Mandal's posts - shared: 
"Gopal babaji kichhudin age mara gelo (in Nainital) shekhane government shob achar-achoron korte dieche, sheta bhalo lage $j$ ontoto apniye nichhe sarkar. Ei dhorun $j$ Gopal babaji, ami jotodur jani, neutral ekta manush. Thakur'der pore aro onek pagol-gosain ache jader kotha apni hoeto shunechen, tader pore ei Gopal babaji emon ekjon jini Dineshpur'e ebong puro Bharotborshe aloron felechen. Dhorte paren ei shoktir ekta central point uni. Uni (Gopal gurudeb) graduate chhilen, shikkhok chhilen, kintu uni shei jibon chhere mathe neme gechilen. Ei moddhe jeta bhalo lage, $j$ ajke government kichuta gurutto dichhe. Apni bollen eta amio shunini - amrao toh 'backward', Andaman'e thaki, shob khobor ashena - j Thakurnagar'er mati Ayodhya te mandir sthaponar jonno dewa hoeche. Eta onek sentimental byapar kintu! Thakurnagar'er mati k etota gurutto diechhe."

(The Matua guru, Gopal, passed away in Nainital sometime back and the Uttarkhand government took the initiative to conduct his funerary rites, it feels good to see that the government has honoured him. He was, as far as I know, a neutral person. After the (Harichand and Guruchand) Thakurs, there were other Matua luminaries and Gopal babaji was one of them, who gained prominence not only in Dineshpur but also the entire country. You could say he is the central point of Matua power. He was a graduate, he taught, but he left that all behind to reach the grassroots. The government's recognition, now, feels really good. Like you said, and I wasn't aware of it - even we are 'backward', living in Andaman, where not all news reaches - that the soil from Thakurnagar was sent to Ayodhya for the construction of the Ram temple. This is a sentimental matter for us, that the soil of Thakurnagar has been given so much importance!)

The consistent use of adjectives such as 'distant' and 'backward' to describe the islanders' location (Ratter, 2018), in addition to affirming their current context of 'islandness' (Baldacchino, 2018), also acknowledges their historic trajectory of multiple displacements and the active role of religion in binding the island with the mainland (Lorea, 2017). This sense of 'insularity' - a result of both the island geography as well as its psychological impact, or the interplay of 'natural and cultural aspect of islands' (Pungetti, 2013: 52) - is shaped by the settlers' interactions with 'mainlanders'. While insularity can arise from other geographical settings (for instance, the Dandakaranyas, where dispersed Namasudras were settled), Baldacchino and Veenendaal (2018: 339-340) concur, "there is nothing quite similar to the sea in how it acts as transportation highway, border, climate moderator and source of protein", setting the island-settlers apart from their dispersed counterparts in the Indian mainland. 'Islandness' is constituted by boundedness, smallness, isolation, fragmentation, and amplification by compression (Baldacchino, 2018), yet 'islandness' produces paradoxes and hybridity (Larjosto, 2020: 40), as the 'tropes of islandness' include "tradition/modernity, dependency/autonomy, roots/routes, globalisation/particularity, vulnerability/resilience" that exist in continuum rather than binaries (Royle and Brinklow, 2018: 11). The settlers' 'islandness' is not only acquired by transportation to the island, instead it is earned by their decision to live on an island and by the processes required in settling themselves. This choice of living in an island and earning ones islandness becomes central in understanding their islander identity and its contrast with in-migrants' 'outsider' identity (Royle and Brinklow, 2018: 12). In an exchange from early-September 2020, Animesh Mandal stated that Matuas were against Brahmanism and not Brahmins themselves and a commentor responded, when the Namasudras in Andaman get their rightful recognition as Scheduled Caste that will be the ideal way of respecting Harichand and Guruchand Thakur, the proponents of Matua religion. Recognised as Scheduled Caste in West Bengal, the dispersed Namasudra people did not receive the same statist recognition - and by extension, rights - in the Andaman Islands, where, in 2005, they were categorised as OBCs (Other Backward Classes) along with other settler populations (Banerjee, 2009; Lorea, 2017). In contrast with 'outsiders', the islanders invoke their 'insider status' to "affirm their rights regarding employment (especially in the public sector), housing, and a variety of public goods" (Baldacchino and Veenendaal, 2018: 348). Divided, dispersed, and deprived of (physical) homeland, network, and political rights and bargaining power, online deliberations of the Island's Matua community revolve around issues of assigning a unified Matua identity and privileging certain 
memories and identities over others. During the socially-distanced and crisis-ridden times of the pandemic, however, this 'islander' identity is advanced by the islanders as a 'privileged' identity. ${ }^{4}$ Moreover, during this time islands have been portrayed as 'uncontaminated' spaces, both by the tourism industry as well as islanders themselves, whereby rural islanders and Matua practitioners claim this rurality as the antidote to contracting the virus. The pandemic has, in fact, reaffirmed the settler Matua devotees' sense of 'islandness' and such islandness is perceived and presented as a positive attribute in guarding against viral infections.

\section{Recording 'virtually' absent voices}

With the introduction of under-sea cable for greater internet connectivity in August 2020 (The Hindu, 2020), I was under the impression that it would be easier to connect with island residents over phone calls, even where connectivity was otherwise notoriously unstable. Further, this coincided with the time when Animesh Mandal became much more active on Facebook, sharing multiple updates a day. My attempts at telephonic exchange with interlocutors, however, debunked this assumption. "Port Blair e ekhon net fast cholche, kintu Diglipur'e ekhono kaj daeni", explained Diglipur-based Sandip Sarkar. Phone connectivity was still very unstable in areas outside of Port Blair and internet connection was as good as non-existent. Between failed attempts at getting through via phone calls, I would often leave text messages over Whatsapp for my interlocutors. These text messages would either reach them a few hours later, or not at all. Further, a respondent in Diglipur, North Andaman, would have to step out of his house in order to be able to hear me over the phone, and as a result of his predicament (after multiple attempts over two months) I was unable to collect his interview. While allied infrastructural development means Matua islanders could find it easier to forge and maintain religious networks virtually, it can also leave out certain actors in the process. In this section, I examine these material conditions which facilitate virtual interaction and the social location of the actors who remain 'disconnected'.

In contrast to the virtual 'field' where Matua practices were being adapted to the 'online' medium, telephonic interviews revealed a lack of islander's participation in online religious events like e-hari sabhas and livestreaming of devotional kirtans. Unlike my netnographic finding, only two respondents maintained that they had heard of global Matua religious congregations being held on social media platforms like Facebook. And in case of both of these respondents, they were not directly involved in participating in these events, though they had heard of such gatherings. Musician Binoy Talukdar ${ }^{5}$ (name changed), who lives in the Junglighat area of Port Blair, had heard of the e-hari sabhas but wasn't able to participate -

"Haan achha! Amio shunechilam, amakeo New York theke phone korechhilo. Amader ekhaneo jana-shona lok ache okhankar. ... Uni ei shongsthar main lok. ... Kintu ei shomporke amar r kichu jana hoeni. ... Amaro oi bhodroloker sathe $r$ dekha hoeni, jana hoeni. Ei coronar jonno kothao jawao jachhe na, jogajog kora jachhe na. Ei obostha $r$ ki. Shudhu amra keno, shara duniya tei erokom."

(Oh yes! Even I have heard about it; I got a call from New York. We have people here who are aware of such things, he is the head of the organisation. But I have not been able to inquire further on the matter. Neither have I been able to meet with the gentleman who provided my number to the organisation. We have been unable to go anywhere or meet anyone because of corona. Why just us, that is in fact the reality for the whole world!)

Binoy Talukdar is a Matua singer and musician with multiple audio and video-cassettes to his credit. He sings kirtans and harisangit (Matua sacred music) at Matua religious congregations across the Islands. He performs along with his team 
of musicians. However, due to the pandemic protocols, he has not been able to meet his team:

"Nijeder practice'e hochhena! (he is audibly exasperated at this condition) Amar sathirao jara dotara bajae, teentara bajae tara bolchhe amra ekhon ki kori! Odike toh boshar jonno ora plan korteche, kintu ami chinta kori j ami jodi boshi tahole ashe-pashe theke objection hoe gele toh osubidha hobe. Shobar toh shob bhalo lage na."

(We are unable to hold practice sessions! My co-musicians are planning to meet for a session, but I am worried if that would create trouble for me. Someone from my neighbourhood might have 'objections' to us congregating. Not everyone likes everything.)

In the urban space of Port Blair, Binoy Talukdar explained, there are very few Matua devotees: "shohorer bhitore, toh eikhane keu Harichand'er bhokto nai, ami chhara" (within the city, there are no Harichand devotees, apart from me), and the Hari mandir in Sippighat is one of the few prominent Matua congregational spaces. For the past year, however, all activities are halted, including the weekly mass feasts held every Wednesday, on account of the pandemic.

During this time, gosains and devotees took the initiative to host festivals at a smaller scale, as Ashok Pal mentioned, a prominent gosain from Port Blair held a similar religious gathering in late-December 2020, which was attended by 250300 people. Under non-pandemic circumstances, such festivals - "resembling the celebrations of Thakurnagar and Orakandi in its style and scale" - are attended by a few thousand devotees from across the Islands. For Diglipur-based Sandip Sarkar ${ }^{6}$ (name changed), who is a prominent member of the local Matua community and hosts an annual threeday Matua Mahotsav, things are going as they used to - "jebhabe age cholchilo shebhabei cholche". The family's guru had travelled to the Islands from West Bengal in late-October 2020. Matua families held small kirtan gatherings in his honour, which were attended by local devotees including Sandip Sarkar who made an offering of clothes (bostro daan) to the gosain, and intends to host him on his next visit to the Islands. The locals seemed to favour a physical congregation over virtual gatherings, relying on technologies like video recordings of kirtans and sabhas for later viewing and seldom as a substitute for in-person attendance. Wandoor-based Matua singer Jiban Bala7 (name changed) explained the instrumental role of Gopal Maharaj in uniting the devotees of two villages in Wandoor: "Gopal shadhu amader duti gram shob Hari mot'e dikkha diye dise. Ei jonne ekta bari sthir kore dieche, j daily toh parba na toh mash'e ek bar tomra ei dui gram'er manush ekotro hoiya gaan-bajna koro" (the saint, Gopal, initiated the people of the two villages to Matua faith, and instructed us to take turns in organising monthly feasts and devotional gatherings, which we continue to this day). These ritual congregations are essential to Matua devotees as the 'shared experience of devotion embodied through participation in congregational singing and dancing created togetherness, belonging, and networks of emotional support' (Lorea, forthcoming), which helped forge a sense of community in the early years of settlement and continue to be a powerful form of identity-making. Ashok Pal, in this context, described the central role of Matua religion for the multiply displaced island-settlers: "Matua shomprodae ekta notun dhoroner culture toiri koreche" (the Matua community has engendered a distinct culture in the islands), that is, as Lorea (2020a: 241) states, 'the religious and cultural identity provided by Matua doctrines, rituals, and narrative repertoires has united Bengali refugees and their descendants, offering a source of dignity, status, and symbolic capital.' Moreover, the organizers, like Sandip Sarkar, too, rarely have the material means to prepare recordings of the events for absent devotees, and all their efforts are geared towards managing the great number of devotees that usually attend the congregations. This year, he shared, "ichha chhilo amra notun kore internet e chharbo" (we wanted to share some of our videos on the internet), but that could not be managed due to the economic uncertainty posed by the pandemic. 
The online 'social network' appears to be a male space, as very few women seemed to engage with Animesh Mandal's Facebook posts, ${ }^{8}$ and indicate a gender divide in accessing technology in the island-space, which belies the 'offline' instances of female devotees' creative engagement with Matua religion. One of the most significant, and somewhat unexpected, findings was the 'emancipatory' potential of religion for a female devotee in Havelock Island (Swaraj Dweep), for whom involvement in the Matua practices was not only religious but also a form of 'escape' from the gendered domestic roles, a purpose that virtual engagement cannot fulfil. Uma $d i^{9}$ (name changed) described her participation in Matua faith through personal challenges and losses, and ultimately finding 'joy':

"My father's house is in Tirur (in South Andaman), where I grew up worshipping all deities. Once married, I would visit the Hari mandir close to our quarters in Havelock. When my husband passed away in April 2010, a neighbour would ask me to accompany her in collecting the money for the upcoming annual Matua festival. My husband used to work in Neil, our children were young, and later we shifted back to Havelock, then my husband passed away and it was around this time I started going to the mandir. Later, when I started visiting Sippighat mandir I felt much more joy than I ever felt before! We were living in Port Blair for a long time, since last July or so, and came back to Havelock after the lockdown was lifted in late May. During this time, it (Matua faith) started influencing me deeply. I used to visit the temple on Wednesdays. I would bring some sweets or something along with me. I would take the bus on my way there and an auto on my way back from the temple. We eat vegetarian food on Wednesdays. Even a year back I didn't know one word of 'bandana' (prayer), so I started wanting to know more. I learnt about 'roop bandana', 'mangalachar', (various aspects of Matua prayer) etc. I bought a book for Rs. 100 (while living in Bhatubasti) to know more about these things."

Her interest in learning about the religion and participation in activities related to organising Matua festivals in her village, offer her a chance to express herself in ways beyond the framework of domestic life: "I went to school so many years back, that too I can't recall what I studied. Then 25-30 years were spent over 'shongshar' (domestic life) and raising children." Now in her fifties, Uma di is an active member of the island's Matua community involved in the logistics of organizing the annual Matua Mahotsav, and enjoys attending the night-long kirtan sessions, the energetic matam (a ritual dance that is said to impart spiritual and physical strength):

"You know, everyone is sick and ailing due to the lockdown - ekhane byatha, okhane byatha (it hurts here, it aches there). 'Matam' is really important, because that's a very good exercise. We don't need to exercise otherwise. During 'matam' one sweats profusely (mathar gham paye pore) because of all the movement and that keeps one fit. Keeping up all night, listening to 'thakur naam' (the sacred prayer of the Lord) also makes you think and keeps your mind engaged and fit. Now everyone is home and ailing with aches, and have no one to talk to."

The lack of opportunities to congregate has left her feeling restless and isolated: "Bhalo lage na kirtan na thakle. Youtube'e dekhi - wifi niye niyechi (I don't feel good if there are no kirtans to attend. I watch them on Youtube, for which I bought a Wi-Fi connection.). I did not use phones so much until now. It's during the lockdown that I have starting using it so often." Getting a Wi-Fi connection, however, requires an elaborate plan. After coming back from Port Blair in May 2020, Uma di applied for a new internet connection. Since the boat service was irregular on account of pandemic restrictions, the router, which is shipped from Port Blair, could only be sent over to Havelock once the boat service started. After a few months, when the router reached the post-office in Havelock, it was finally brought over to her house. The entire process took her a few months. A few months later, in early February 2021, they were able to organize the annual Mahotsav and when I requested her for photographs and video recordings of the event, she was unable to do so as her cellphone was 
not working and she would have to travel to Port Blair in order to get a new one. Islanders suffered even more due to lack of inter-island connectivity than their 'disconnect' with the mainland because of the pandemic. Therefore, infrastructural preconditions extend beyond the availability of cell phones, phone network, Wi-Fi network, and undersea cables, to the more immediate and tangible material conditions, like regular boat service, in order for islanders to 'connect' with the 'centre', that is, Port Blair, from the peripheries of the archipelago itself. Absence of these material conditions result in the absence of certain actors from virtual processes which have come to define human interaction in the pandemic-age, reinforcing attributes of 'remoteness' and 'peripherality' attached to people and places.

\section{Conclusion}

The apparition of 'isolation' that is said to have haunted the island-scape (Jędrusik, 2011; Pungetti, 2013) gained new meaning in the context of the pandemic. The paper argues that islanders and island-spaces experienced the pandemic uniquely - demonstrating this with the case of the Matua settlers in the Andaman Islands - resulting both from their geographic location, that is, an island, as well as, the community's shared history of displacement(s) and dislocation. By analysing the devotee's digital expression of their religious and 'islander' selves, the paper highlights the settler's usage of 'remoteness' of their islanded locations as a positive attribute and their islander identity as a privileged identity in the backdrop of the pandemic. According to their online public religious discourse, the pandemic-induced restrictions on mobility has reaffirmed the settler's 'islandness', which is invoked in online deliberations particularly with actors situated in the Indian mainland. It is particularly curious to study these expressions and representations of 'remoteness' in the context of a religious community which has historically experienced multiple displacement(s) across generations and operates within a vast now-global faith network. However, issues of connectedness and disconnect rise from material conditions like availability of infrastructure and access to technology. The unequal access to these result in 'absent' actors, predominantly women, from the religious deliberations. Further, as the archipelago's islands became 'isolated' from other islands with infrequent boat service and weak cellular networks to sustain interaction, the actors suffered from 'disconnect' not only from the Indian mainland, but more importantly from the lack of inter-island connectivity. Matua religion, which has historically been a unifying aspect of the island-settlers' 'isolated' existence with the majority of the Namasudra community in the mainland, adapted to remote means of connecting to the religious network. However, 'isolation' from larger Matua community on account on 'islandness' cannot be addressed without material facilities like, boats, mobiles and the internet. In the absence of these conditions, islanders of specific gender-caste-class identity remain absent from the virtual platforms and thus, disconnected from the larger community. For a community that values the central role of faith in healing - "bhokti-bishwash thakle tahole rog'o toh dure thake"10 (diseases stay afar if one has faith and belief) - 'remoteness', especially restrictions on inter-island mobility, can be as acute a problem as the pandemic itself.

\section{Acknowledgements}

I would like to thank Dr. Carola Lorea for giving me the opportunity to work on this innovative project, and to both Dr. Lorea and Dr. Natalie Lang for their valuable comments on the draft of this paper. Thanks are also due to the organizers, speakers and participants of the workshop on 'Religion and the Covid-19 Pandemic: Mediating Presence and Distance', Asia Research Institute, National University of Singapore, held 'virtually' in late April 2021. Finally, and most significantly, I am grateful to the research participants for accommodating our remote interactions during these difficult times. 


\section{Endnotes}

1. "Although no official figures are available, local observers on the Islands believe that the Matuas constitute over 80 per cent of the Bengali settler population on the Islands."

2. "... islandness: a term that I, along with an expanding list of others, opt to use to represent all that constitutes an island; a distilled and judgement-free sense of island living. This is preferred to the more commonly used term insularity, since this particular word comes along with a considerable adverse baggage in the English language, which is then unfairly foisted on island spaces and their peoples: backwardness, parochialism, small-mindedness. Islandness is the more neutral choice, and so does not linguistically pre-condemn islands and islanders to a negative assessment." (Baldacchino 2018: xxiv)

3. Telephonic interview with Ashok Pal (name changed), held between November 2020 and February 2021.

4. Marlene Chapman's work (GUEST OPINION: Islandness: A COVID-19 superpower? | SaltWire) also demonstrates the projection of islandness as a positive attribute in keeping Covid infections out of island spaces.

5. Telephonic interview with Binoy Talukdar (name changed), held between November 2020 and February 2021.

6. Telephonic interview with Sandip Sarkar (name changed), held between October 2020 and February 2021.

7. Telephonic interview with Jiban Bala (name changed), held between November 2020 and February 2021.

8. Moreover, AM's choice of pronouns, too, seem to favour male devotees. Writing about a booklet on the Matuas of Andaman, published by the Sippighat Hari Mandir, AM mentions that the material will be particularly useful for (male) research students (chhatro).

9. 'di' is short for 'didi' meaning elder sister in Bengali; Telephonic Interview with Uma di (name changed), held between November 2020 and February 2021.

10. Telephonic interview with Jiban Bala (name changed), 16 November 2020.

\section{References}

Anderson, C., Mazumdar, M., Pandya, V., 2016. Introduction, in: Anderson, C., Mazumdar, M., Pandya, V. (Eds.), New Histories of the Andaman Islands: Landscape, Place and Identity in the Bay of Bengal, 1790-2012. Cambridge University Press, Delhi, pp. 1-25.

Bandyopadhyay, S., 2016. Bangali dalit bastuhara manush (Bengali dalit land-lost people). Akademi Patrika 37, Paschimbanga Bangla Akademi Journal. 37: 83-99.

Banerjee, H., 2009. Reservation policy a controversial affair in island's society. The Indian Journal of Political Science. 70(3): 813-824.

Baldacchino, G., 2018. Preface, in: Baldacchino, G. (Ed.), The Routledge International Handbook of Island Studies: A World of Islands. Routledge and Taylor \& Francis Group, Oxon and New York, pp. xix-xxxv.

Baldacchino, G., Veenendaal, W., 2018. Society and Community, in: Baldacchino, G. (Ed.), The Routledge International Handbook of Island Studies: A World of Islands. Routledge and Taylor \& Francis Group, Oxon and New York, pp. 339-352.

Burholt, V., Scharf, T., Walsh, K., 2013. Imagery and imaginary of islander identity: older people and migration in Irish small-island communities. Journal of Rural Studies. 31: 1-12.

Byapari, M., 2013. Itibritte Chandal Jivan: An Autobiography by Manoranjan Byapari (Vol I) (in Bangla). Kolkata Prakashan, Kolkata. 
Chatterji, J., 2001. Right or Charity? The Debate over Relief and Rehabilitation in West Bengal, 1947-50, in: Kaul, S. (Ed.), The Partitions of Memory: The Afterlife of the Division of India. Indiana University Press, Bloomington, Indiana, pp. 74-110.

Hine, C., 2000. Virtual Ethnography. SAGE Publications Ltd., London, California and New Delhi.

Hine, C., 2017. From Virtual Ethnography to the Embedded, Embodied, Everyday Internet, in: Hjorth, L., Horst, H., Galloway, A., Bell, G. (Eds.), The Routledge Companion to Digital Ethnography. Routledge, New York and Oxon, pp. 21-28.

Jalais, A., 2005. Dwelling on Morichjhanpi: when tigers became 'citizens', refugees 'tiger-food'. Economic and Political Weekly. 40(17): 17571762.

Jędrusik, M., 2011. Island studies. island geography. but what is an island?. Miscellanea Geographica. 15: 201-212.

Kozinets, R. V., 2010. Netnography: Doing Ethnographic Research Online. SAGE Publications Ltd., London, California, New Delhi and Singapore. Larjosto, V., 2020. Islands of the anthropocene. Area. 52: 38-46.

Lorea, C. E., 2017. Bengali settlers in the Andaman Islands: the performance of homeland. IIAS The Newsletter. 77: 4-5.

Lorea, C. E., 2020. Religion, Caste, and Displacement: The Matua Community. Oxford Research Encyclopaedia of Asian History. (Religion, Caste, and Displacement: The Matua Community I Oxford Research Encyclopedia of Asian History)

Lorea, C. E., 2020a. Contesting multiple borders: bricolage thinking and Matua narratives on the Andaman Islands. Southeast Asian Studies. 9 (2): $231-276$.

Lorea, C. E., Forthcoming. An Untouchable Kirtan: Sonic Liberation on the Andaman Islands. Sounding the Ocean.

Mallick, R., 1999. Refugee resettlement in forest reserves: West Bengal policy reversal and the Marichjhapi massacre. The Journal of Asian Studies. 58 (1): 104-125.

Mani, S., Barooah, B., 2020. Phone surveys in developing countries need an abundance of caution. April 9, 2020 (Phone surveys in developing countries need an abundance of caution | 3ie (3ieimpact.org)).

Mazumdar, M., 2016. Dwelling in fluid spaces: the Matuas of the Andaman Islands, in: Anderson, C., Mazumdar, M., Pandya, V. (Eds.), New Histories of the Andaman Islands: Landscape, Place and Identity in the Bay of Bengal, 1790-2012. Cambridge University Press, Delhi, pp. 170200.

Mehra, A., Saini, S., Tirumkudulu, M. 2020. A Homeopathic Defence Against COVID-19 Is No Defence At All. June 14, 2020 (A Homeopathic Defence Against COVID-19 Is No Defence at All - The Wire Science).

Pungetti, G., 2013. Islands, culture, landscape and seascape. Journal of Marine and Island Cultures. 1(2): 51-54.

Ratter, B. M. W., 2018. Introduction to the Geography of Small Islands, in: Ratter, B. M. W. (Ed.), Geography of Small Islands: Outposts of Globalisation. Springer, Cham, pp. 1-24.

Royle, S. A., Brinklow, L., 2018. Definitions and Typologies, in: Baldacchino, G. (Ed.), The Routledge International Handbook of Island Studies: A World of Islands. Routledge and Taylor \& Francis Group, Oxon and New York, pp. 3-20.

Sen, J., 2015. Reconstructing Marichjhapi: From Margins and Memories of Migrant Lives, in: Butalia, U. (Ed.), Partition: The Long Shadow. Zubaan and Penguin Books India, Heinrich Boll Foundation, Delhi, pp. 102-127.

Sen, U., 2017. Memories of partition's 'forgotten episode': refugee resettlement in the Andaman Islands. Südasien-Chronik - South Asia Chronicle. 7: 147-178.

Sen, U., 2018. Citizen Refugee: Forging the Indian Nation after Partition. Cambridge University Press, Cambridge.

The Hindu, 2020. PM Modi launches submarine optical fibre cable to Andaman \& Nicobar Islands. August 10, 2020 (PM Modi launches submarine optical fibre cable to Andaman \& Nicobar Islands - The Hindu). 